\title{
Demokrasi di Malaysia: Studi Perbandingan Periode Pemerintahan Tiga Perdana Menteri Malaysia
}

\author{
Mohammad Fauzi \\ Staf Pengajar Prodi SKI Fakultas Adab/Humaniora, UIN Sunan Ampel Surabaya. \\ Jl ahmad Yani 117, Surabaya 60237 \\ Email: aswajar@gmail.com \\ Diterima pada 09 Juli 2014, Disetujui pada 21 Februari 2015
}

\begin{abstract}
This study aimed to compare the historical descriptive-interpretative effect general election implementation and socio-economic and cultural conditions of democracy and democratic process in Malaysia during the government period of Tunku Abdul Rahman to Mahathir Mohamad. The research based on the secondary data study-method. Based on the research, the general election implementation and socio-economic and cultural condition do not significant effect on democracy and the democratic process in Malaysia, except in the middle of Tun Abdul Razak's government which the socio-economic conditions have a significant effect on democracy in Malaysia.

Keywords: cultural, democracy, democratic process, general elections, socio-economic
\end{abstract}

\begin{abstract}
Abstrak
Studi ini bertujuan membandingkan secara deskriptif-interpretatif historis pengaruh pelaksanaan pemilihan umum dan kondisi sosial-ekonomi dan budaya terhadap demokrasi dan proses demokrasi di Malaysia selama periode pemerintahan Tunku Abdul Rahman hingga Mahathir Mohamad. Penelitian ini didasarkan pada studi-metode data sekunder. Berdasarkan penelitian, pelaksanaan pemilihan umum dan kondisi sosial-ekonomi dan budaya tidak berpengaruh signifikan (positif) terhadap demokrasi dan proses demokrasi di Malaysia, kecuali pada pertengahan pemerintahan Tun Abdul Razak, yang mana kondisi sosial-ekonomi memberikan pengaruh signifikan pada demokrasi di Malaysia.

Kata kunci: budaya, demokrasi, pemilihan umum, proses demokrasi, sosial-ekonomi
\end{abstract}

\section{PENDAHULUAN}

Malaysia merupakan salah satu negara di Asia Tenggara yang memiliki pengalaman unik dalam melembagakan demokrasi. Faktor bekas jajahan Inggris (Varshney, 1998: 38; Huntington, 1992: 91; Huntington, 1995: 54), kondisi ekonomi (Potter, 1997: 11-12; Wilhelmsen, 2006: 41; Vanhanen, 1997: 11-12; Varshney, 1998: 41) dan sosial-budaya (Diamond, 2003: 210-211; Diamond, 2002: 24; Vanhanen, 1997: 12) yang menurut pelbagai ilmuan politik sebagai faktor pendukung berkembangnya demokrasi ternyata di Malaysia memiliki pengaruh kompleks dan kontradiksi. Pada satu sisi ketiga faktor ini mempengaruhi perkembangan demokrasi dan pada sisi lain mendorong pemerintah mmengontrol masyarakat dengan alasan stabilitas politik dan pembangunan ekonomi. Fenomena ini menjadi permasalahan dalam mengklasifikasikan rezim politik Malaysia.

Secara konstitusional, menurut beberapa ilmuan sosial-politik dan elite politik Malaysia sistem politik dan pemerintahan Malaysia demokratis.

Argumentasinya, negara ini memilih pemimpin pemerintahan tingkat nasional maupun lokal berdasarkan pemilihan umum (general election) (Abas, 1968: 155-156; Bedlington, 1997: 234). Pemilu 
sebagai syarat mutlak demokrasi modern dilaksanakan secara konsisten di Malaysia (Mohamad, 1999: 51).

Kemunculan institusi demokrasi di Malaysia diperkenalkan Inggris di masa penjajahan (Johnson dan Milner, 2005: 81-108; Bedlington, 1997: 234235), melalui kebijakan reformasi pemerintah kolonial Inggris yang bertujuan mentransfer kekuasaan pada perwakilan masyarakat di Malaysia. Kebijakan ini ditetapkan dalam Perjanjian Federasi Malaya Tahun 1948. Berdasarkan perjanjian ini: (1) Inggris memberikan kekuasaan kepada orang Melayu untuk mendirikan sistem federasi, (2) kerajaan-kerajaan Melayu menjadi monarki konstitusional (constitutional monarchy), (3) terbentuk dewan legislatif federal yang terdiri dari orang Malaya, (4) kuasi-kabinet dibentuk, dan (5) pemilu legislatif tingkat federal dilaksanakan tahun 1955. Perjanjian ini menjadi cetak biru Konstitusi "Merdeka" Malaya setelah menjadi negara merdeka (Bedlington, 1997: 138 dan 234-236; Abas, 1968: 24).

Dalam Konstitusi "Merdeka" Malaya sistem politik dan pemerintahan Malaysia memiliki karakteristik: (1) bentuk negaranya adalah federal, (2) bentuk pemerintahannya adalah monarki konstitusional, (3) sistem pemerintahannya adalah parlementer, dan (4) lembaga yudikatif atau badan peradilan bersifat independen hampir mirip seperti badan peradilan Inggris.

Institusi politik ini pada perkembangannya diperkuat oleh: pertama, pertumbuhan pembangunan ekonomi dimana rata-rata Gross National Product (GNP) dan Gross Domestic Product (GDP)-nya per kapita tahun 1957-2003 sebesar 0,2\%-7,8\% dan 1,4\%-8,7\% (EPU Malaysia, 2001; World Bank, 2008; UNDP, 2006: 23). Pertumbuhan ini merupakan pengaruh positif NEP (New Economic Policy), NDP (National Development Policy), dan NVP (National Vision Policy) (Abdullah et al., 2007: 214; UNDP, 2006: 24). Dampak pertumbuhan ini melahirkan kelas menengah baru terdidik yang memiliki kesadaran politik yang sangat berpengaruh pada pembagunan demokrasi di Malaysia (Ahmad dan Alatas, 1999: 194-195).

Kedua, faktor sosial-budaya dengan orientasi nilainya mendukung demokrasi. Meskipun Malaysia merupakan negara Muslim yang memiliki keragaman etnis, agama, dan budaya karena pemerintahan ditetapkan bersifat pluralis sehingga organisasi sosialpolitik diberi tempat untuk berkontestasi dan berpartisipasi dalam proses politik dan pemerintahan (Esposito dan Voll, 1999: 165-166), bahkan, oposisi dapat menguasai pemerintahan Negara Bagian (Mohamad, 1999: 50).

Pengakuan negara terhadap keragaman organisasi sosial-politik, budaya, dan ekonomi tampak terlihat pada Konstitusi Federal Malaysia (Federal Constitution of Malaysia). Secara normatif Konstitusi Federal Malaysia mengakui kebebasan masyarakat sipil (Constitution of Malaysia, Bagian II - Fundamental Liberties dan Bagian III - Elections; Milne dan Mauzy, 1978: 42; Abas, 1968: 343-359), yang diakui dalam batasanbatasan tertentu, yaitu ketentuan nilai-nilai yang berkembang di masyarakat negara Malaysia (Mahathir, 1999: 50-51 dan 82).

Namun demikian, faktor penjajahan Inggris, kondisi ekonomi, dan kondisi sosial-budaya tidak selalu berpengaruh positif terhadap demokrasi dan demokratisasi di Malaysia, bahkan pada periode National Operations Council (NOC) memperkuat rezim otoriter. Hubungan yang begitu lama dengan Inggris tidak selalu memberikan pengaruh positif terhadap demokrasi di Malaysia, meskipun membuat Konstitusi Malaysia memakai model demokrasi Inggris, tetapi pemerintah melakukan kontrol otoritarian terhadap kebebasan sipil dan politik melalui pelbagai peraturan represif. Peraturan ini menjadi media justifikasi jangka panjang pemerintah untuk membatasi kebebasan sipil dan politik dan memberikan kewenangan memberantas gerakan komunis, komunalis, dan organisasi sosial-politik oposisi yang menjadi musuh dan mengganggu stabilitas Negara (Milne dan Mauzy, 1978: 358; Mohamad, 1999: 30; Heufers, 2002: 45 dan 56).

Secara konstitusional awalnya rezim politik dan pemerintahan Malaysia demokrasi parsial dan kemudian pada perkembangannya terjadi involusi rezim politik. Di awal kemerdekaan rezim politik dan 
pemerintahan Malaysia adalah demokrasi parsial dan pada perkembangannya pada pemerintahan Tunku Abdul Rahman rezim rezim ini diikuti praktik feodalisme (feudalism). Rezim demokrasi parsial ini kemudian menjadi rezim otoriter ketika pemerintahan dipegang oleh NOC. Sejak pemerintahan dipegang Mahathir Mohamad menjadi pemerintahan otoriter yang didominasi Melayu (Milne dan Mauzy, 1978: 355-364).

Tidak berbeda dengan konstitusinya, pertumbuhan ekonomi memberikan pengaruh kompleks dan kontradiksi terhadap perubahan rezim politik Malaysia, di satu sisi memberikan pengaruh terhadap kecenderungan pemerintah mengontrol lebih otoritarian kepada masyarakat dan di sisi yang lain memperkuat resistensi demokratis masyarakat. Sejak diberlakukan New Economic Policy (NEP) hingga National Vision Policy (NVP) pertumbuhan ekonomi di Malaysia cukup pesat dan akibat pertumbuhan ekonomi ini muncul pemerintahan yang kuat, yang didominasi etnis Melayu dan terkonsolidasi pada pemerintahan Mahathir Mohamad. Kemenangan Barisan Nasional (National Front) pada pemilu 19861999 sepertinya memberikan mandat kepada pemerintah untuk intervensionis, meskipun pada waktu bersamaan pemerintah masih mempertahankan institusi dan praktik demokratis. Pada satu sisi pemerintah membatasi hak politik dan kebebasan sipil sehingga membuat kebijakan pemerintah tidak demokratis dan pada sisi yang lain menguatkan proses demokratis (Ahmad dan Alatas, 1999: 176-178). Intervensi pemerintah dilakukan melalui metode persuasif dan paksaan dengan alasan menciptakan kestabilan politik, persatuan nasional, dan pembangunan ekonomi. Dampak destruktif dari NEP hingga NVP membuat etnis non-Melayu teralienasi dalam proses dan distribusi hasil pembangunan dan kesenjangan kesejahteraan di internal komunitas Melayu (Koon, 1997: 214; Abdullah et al., 2007: 214).

Selain persoalan tersebut, lemahnya pelembagaan demokrasi di Malaysia karena dipengaruhi oleh rapuhnya ko-eksistensi terhadap keragaman etnis dan menguatnya komunalisme antaretnis yang dipengaruhi disparitas sosial-ekonomi yang bersifat struktural dan berakar sejak masa kolonialisme Inggris. Akibat hal ini terjadi kerusuhan antaretnis tahun 1969 (Abdullah et al., 2007: 217; Guan, 2000: 20 dan 37). Pasca kerusuhan etnis, dengan tujuan normalisasi kondisi politik dalam negeri, diproklamirkan Rukunegara sebagai ideologi baru negara Malaysia. Berdasarkan ideolog1 ini Melayu menjadi dominan yang memiliki hak istimewa di bidang pelbagai bidang (Ahmad dan Alatas, 1999: 187; Esposito dan Voll, 1999: 169-171).

Sampai pada deskripsi ini, tampak bahwa praktik dan pelembagaan demokrasi di Malaysia masih mengalami pelbagai permasalahan. Masalahnya diantaranya terletak pada pelaksanaan pemilu dan kondisi sosial-ekonomi dan budaya di Malaysia. Oleh karena itu untuk memahami masalah ini pemaparan interpretatif pengaruh faktor tersebut terhadap demokrasi dan proses demokrasi di Malaysia menjadi sangat penting.

\section{METODOLOGI}

TUJUAN PENELITIAN

Secara umum penelitian ini bertujuan membandingkan secara deskriptif-historis demokrasi di Malaysia pada pemerintahan Tunku Abdul Rahman hingga Mahathir Mohamad. Sementara tujuan spesifiknya penelitian ini ialah membandingkan secara deskriptif-historis pengaruh pelaksanaan pemilu, sosialekonomi, dan budaya terhadap demokrasi dan proses demokrasi di Malaysia pada pemerintahan tersebut.

\section{TINJAUAN PUSTAKA}

Demokrasi dalam perspektif prosedural ialah sistem atau rezim politik dan pemerintahan yang dibangun atas preferensi melalui pemilu yang bersifat periodik, terbuka, bebas, dan adil-yang di dalamnya setiap warga negara dapat berkontestasi, berpartisipasi, dan hak-hak politik dan kebebasan masyarakat sipil dilindungi dan dijamin. Indikator demokrasi meliputi: (1) kontestasi, (2) partisipasi, dan (3) kebebasan politik dan sipil (Schumpeter, 1987: 269; Huntington, 1995: 6-7; Sorensen, 2003: 14-19; Diamond, 2002: 21-22; Vanhanen, 1997: 29). Sedangkan dalam perspektif 
komprehensif demokrasi merupakan konsep demokrasi yang diperluas dari demokrasi politik, dimana cakupannya tidak hanya dalam sistem politik tetapi juga mencakup sistem sosial dan ekonomi. Prinsip-prinsip dasar demokrasi ini adalah otonomi demokratis yang berada pada pada level negara dan masyarakat (Held, 1996: 296-301 dan 324-325; Sorensen, 2003: 24).

Indikator tersebut dapat dipergunakan untuk mengklasifikasikan rezim politik. Klasifikasi rezim tersebut: (1) demokrasi liberal, (2) demokrasi parsial, (3) otoriter. Rezim demokrasi liberal ialah rezim politik dan pemerintahan berdasarkan pada aturan dan kebijakan publik yang dibuat oleh perwakilan masyarakat yang bertanggung jawab kepada masyarakat melalui pemilu yang bebas, adil, dan kompetitif dan menjamin hak-hak politik dan kebebasan masyarakat sipil, dan otonomi asosiasi. Rezim demokrasi parsial ialah rezim politik dan pemerintahan yang pertanggungjawabannya kepada masyarakat kurang berkualitas, dilakukan secara terbatas hanya melalui pemilu yang tidak bebas, adil, dan kompetitif, dan pembatasan terhadap hak-hak kebebasan berekspresi, dan otonomi asosiasi. Sedangkan rezim politik otoriter ialah rezim politik gabungan dimana para pemimpin politik yang berkuasa tidak bertanggung jawab kepada masyarakat melalui pemilu, membatasi hak-hak politik dan kebebasan masyarakat sipil, dan melarang serta memberangus asosiasi yang otonom dan kritis (Potter, 1997: 4-5).

Ketiga rezim politik tersebut yang menjadi standar global negara di dunia adalah rezim demokrasi. Perubahan rezim ini diperjuangkan oleh para pendukung rezim demokrasi dari rezim otoriter kepada rezim demokrasi. Proses ini disebut dengan demokratisasi (Verhulst dan Nijeboer, 2007: 7), yakni proses perubahan politik dari rezim politik tidak demokratis kepada rezim politik demokratis yang terbentuk melalui transformasi, replacement, transplacement, dan intervensi (Huntington, 1995: 13 dan 45; Potter, 1997: 3).

Transisi demokrasi terjadi ketika elite berkuasa, kelompok oposisi, gabungan antara keduanya dan aktor dari luar negara mempelopori proses perwujudan demokrasi. Medianya dilakukan melalui kompromi, pemilu, dan tindakan non-kekerasan dan kekerasan. Transformasi ialah transisi demokrasi terjadi ketika elite berkuasa mempelopori proses perwujudan demokrasi melalui kompromi, pemilu, dan tingkat kekerasan yang rendah. Replacement ialah transisi demokrasi terjadi ketika kelompok oposisi mempelopori proses perwujudan demokrasi melalui kompromi, pemilu, dan tingkat kekerasan yang rendah. Transplacement ialah transisi demokrasi terjadi ketika elite berkuasa dan kelompok oposisi mempelopori proses perwujudan demokrasi melalui kompromi, pemilu, dan tingkat kekerasan yang rendah. Sedangkan intervensi ialah lembaga demokratis dibentuk dan dipaksakan oleh aktor dari luar tanpa melalui kompromi, pemilu, dan tingkat kekerasan yang tinggi (Huntington, 1995: 146 dan 212).

Demokratisasi ini dipengaruhi oleh faktor, diantaranya faktor: (1) sosial-ekonomi, dan (2) struktur kekuasaan. Pembangunan sosial-ekonomi mempengaruhi terhadap demokratisasi karena keberhasilan pembangunan sosial-ekonomi meningkatkan kesadaran masyarakat kelas bawah pada politik dan peningkatan kelas menengah yang kemudian mempengaruhi terhadap muncul dan terlembanganya demokrasi di suatu negara. Pembangunan sosial-ekonomi dapat berkorelasi signifikan apabila hasil pembangunan terdistribusi secara merata kepada masyarakat dan hal ini dapat terjadi hanya apabila terdapat otonomi dan kontrol atas kekuasaan (Huntington, 1992: 77-84).

Struktur kekuasaan-seperti hubungan priyayi pemilik tanah, petani, dan borjuis kota-mempengaruhi demokratisasi suatu negara, apabila golongan borjuis kuat dan independen muncul sebagai kekuatan resisten terhadap kepentingan rezim otoriter dan mampu melakukan kontrol kebijakan nasional ketika pengaruh petani lemah sekali akibat dihancurkan oleh para pemilik tanah dan kelompok lain yang terlibat pada proses komersialisasi petani (Huntington, 1992: 81-95; Di Palma, 1997: 3; Varshney, 1998: 41-42; Potter, 1997: 10-22). 


\section{METODE PENELITIAN}

Penelitian ini adalah studi perbandingan politik kualitatif-historis (Ragin et al., 1996: 757-758; Pennings et al., 2006: 137 dan 265; Rihoux, 2008: 723) dengan pendekatan deskriptif-interpretatif. Unit analisis penelitian adalah negara Malaysia dan unit pengamatannya ialah kombinasi antara struktur sosialbudaya dan ekonomi, institusi formal di dalam negara, dan organisasi sosial-politik masyarakat di Malaysia. Sumber data yang dipergunakan adalah data sekunder. Metode pengumpulan datanya adalah dokumentasi yang dilakukan dengan menggunakan instrumen dokumentasi (Denzin dan Lincoln, 1994: 9).

Teknik pengolahan dan analisa data penelitian menggunakan metode analisis kualitatif (Neuman, 2000: 420), yang dilakukan pada dua tahap, yaitu: (1) analisa data selama proses penelitian berlangsung, dan (2) analisa data pasca pengumpulan data (Huberman dan Miles, 1994: 429). Langkah analisisnya: (1) reduksi data, (2) penyajian data, dan (3) penarikan kesimpulan atau verifikasi (Huberman dan Miles, 1994: 428-429.). Keabsahan (trustworthiness) data menggunakan uji: (1) kredibilitas, (2) keteralihan, (3) kebergantungan, dan (4) kepastian (Moleong, 2000: 173 dan 190).

Uji kredibilitas menggunakan strategi trianggulasi (triangulation strategy): (1) pengukuran dan sumber, (2) pengamat, (3) teori, dan (4) metode (Neuman, 2000: 124-125). Uji keteralihan data menggunakan uraian rinci, uji kebergantungan data menggunakan teknik pemeriksaan kebergantungan, dan uji kepastian data menggunakan keabsahan data baik proses penelitian maupun data penelitian yang diperoleh (Moleong, 2000: 183-198).

\section{HASIL DAN PEMBAHASAN}

Berdasarkan data penelitian selama pemerintahan Tunku Abdul Rahman hingga Mahathir Mohamad pelaksanaan pemilu di Malaysia adalah tidak demokratis dan kondisi sosial-ekonomi dan budayanya trendnya terus meningkat. Karateristik pelaksanaan pemilunya secara umum dilakukan secara periodik tetapi tidak bebas dan adil, yakni tidak kompetitif, inklusif, dan representatif karena terdapat pembatasan hak-hak politik dan kebebasan sipil (Alvares et al., 1999: 6; International IDEA, 2008; Diamond, 2002: 25 dan 30).

Praktik pemilu ini dijalankan dengan sistem pluralitas-mayoritas model sistem First Past the Post (FPTP) dengan sistem pemilihan dan pencalonan Single-Member-Districts (SMD). Pada periode pemerintahan Tunku Abdul Rahman pemilu dilaksanakan berdasarkan Konstitusi "Merdeka" Malaya Tahun 1957 dan Konstitusi Malaysia Amandemen Tahun 1960, 1962, dan 1963, pada periode pemerintahan Tun Abdul Rahman-Hussein Onn berdasarkan Konstitusi Malaysia Amandemen Tahun 1973, dan pada periode pemerintahan Mahathir Mohamad berdasarkan pada Konstitusi Malaysia Amandemen Tahun 1984 (Hai, 2002: 105112; Koon, 1996: 43).

Sedangkan karakteristik kondisi sosial-ekonomi dan budayanya di tiga periode pemerintahan tersebut trendnya selalu mengalami peningkatan positif di bawah kendali regulasi represif, kebijakan pembangunan-seperti NEP, NDP, dan NVP-dan budaya politik tidak demokratis. Pergerakan trendnya, dari kondisi sosial-ekonomi dan budaya yang berada di level bawah menjadi berada di level menengah bawah dan atas (UNDP, 1994: 105; UNDP, 2006: 55; UNDP, 2007: 234-237).

Data empiriknya pelaksanaan pemilu: (1) periode Pemerintahan Tunku Abdul Rahman menurut data Tatu Vanhanen kompetisi sebesar 28,3\%-45,2\% dan partisipasi 18,9\%-22,7\% (Vanhanen, 1997: 88, 253, dan 272), (2) periode pemerintahan Tun Abdul RazakHussein Onn menurut data Freedom House hak-hak politik sebesar 2-3 dan kebebasan sipil 3-4 (Freedom House, 2006; International IDEA, 2008) ${ }^{1}$ dan menurut data Tatu Vanhanen kompetisi 27\%-45,5\% dan partisipasi 11\%-15,9\% (Vanhanen, 1997: 88, 253, dan 272), dan (3) periode Pemerintahan Mahathir Mohamad menurut data Freedom House hak-hak politik sebesar 3-5 dan kebebasan sipil 4-5 (International IDEA, 2008) dan menurut data Tatu Vanhanen kompetisi 48\% dan partisipasi 31\% 
Tabel 1

Pengaruh Pelaksanaan Pemilu dan Sosial-Ekonomi dan Budaya terhadap Demokrasi dan Proses Demokrasi di Malaysia

\begin{tabular}{|c|c|c|}
\hline Deskriptor & Demokrasi/Proses Demokrasi & Tipe Rezim/Skor \\
\hline \multicolumn{3}{|c|}{ PERIODE TUNKU ABDUL RAHMAN } \\
\hline Pemilu & $\begin{array}{l}\text { - Tidak berpengaruh } \\
\text { > Kompetisi: } 28,3 \%-45,2 \% \\
\text { > Partisipasi: } 18,9 \%-22,7 \%\end{array}$ & Demokrasi parsial \\
\hline $\begin{array}{l}\text { Sosial-ekonomi dan } \\
\text { budaya }\end{array}$ & $\begin{array}{l}\text { - Tidak berpengaruh } \\
\text { > IPR 1,9\% } \\
>\text { Indeks demokratisasi: 5,3\%-10,8\% } \\
>\text { Trend otoritas: + } 10 \text { menurun ke }+1\end{array}$ & \\
\hline \multicolumn{3}{|c|}{ PERIODE TUN ABDUL RAZAK-HUSSEIN ONN } \\
\hline Pemilu & $\begin{array}{l}\text { - Tidak berpengaruh } \\
\text { Freedom House } \\
\text { > Hak-hak politik: 2-3 } \\
\text { > Kebebasan sipil: } 3-4 \\
\text { > Tingkat kebebasan: 2,5-3,5 } \\
\text { Tatu Vanhanen } \\
\text { > Kompetisi: } 27 \%-45,5 \% \\
\text { > Partisipasi: } 11 \%-15,9 \%\end{array}$ & $\begin{array}{l}\text { - Otoriter } \\
\text { - Demokrasi parsial } \\
\text { - Demokrasi }\end{array}$ \\
\hline $\begin{array}{l}\text { Sosial-ekonomi dan } \\
\text { budaya }\end{array}$ & $\begin{array}{l}\text { - Berpengaruh pada tahun 1972-1973 } \\
\text { - Periode yang lain tidak berpengaruh } \\
\text { >IPR 3,7\% } \\
\text { > Indeks demokratisasi: } 10,1 \%-11,5 \% \\
\text { > Trend otoritas: + } 1 \text { meningkat ke }+4\end{array}$ & \\
\hline \multicolumn{3}{|c|}{ PERIODE MAHATHIR MOHAMAD } \\
\hline $\begin{array}{l}\text { Sosial-ekonomi dan } \\
\text { budaya }\end{array}$ & $\begin{array}{l}\text { - Tidak berpengaruh } \\
\text { Freedom House } \\
\text { > Hak-hak politik: } 3-5 \\
\text { > Kebebsan sipil: } 4-5 \\
\text { > Tingkat kebebasan:3-5 } \\
\text { Tatu Vanhanen } \\
\text { > Kompetisi: } 48 \% \\
\text { > Partisipasi: } 31 \% \\
\text { - Tidak berpengaruh } \\
>\text { IPR 10,4\% } \\
\text { >Indeks demokratisasi 14,9\%: } \\
>\text { Trend otoritas: }+4 \text { menurun ke }+3\end{array}$ & Demokrasi parsial \\
\hline
\end{tabular}

Sumber:Vanhanen, 1997; Freedom House, 2006; Marshal dan Jaggers, 2006; International IDEA, 2008

(Vanhanen, 1997: 88, 253, dan 272).

Sedangkan kondisi sosial-ekonomi dan budayanya: (1) periode Pemerintahan Tunku Abdul Rahman menurut data UNDP Human Development Index (HDI) sebesar 0,330-0,471 (UNDP, 1994: 105) dan menurut Tatu Vanhanen Index of Power Resources (IPR)-nya sebesar 1,9\% (Vanhanen, 1997: 55-62, 146, 253, dan $272)^{2}$, (2) periode pemerintahan Tun Abdul Razak-
Hussein Onn menurut data UNDP HDI-nya sebesar 0,619-0,662 (UNDP, 1994, 105; UNDP, 2006: 55; UNDP, 2007: 234-237) dan menurut Tatu Vanhanen IPR-nya sebesar 3,7\%-6,7\% Vanhanen, 1997: 88, 146, 253, dan 272), (3) periode Pemerintahan Mahathir Mohamad menurut data UNDP HDI-nya sebesar 0,696-0,790 (UNDP, 2006: 55; UNDP, 2007: 234 237) dan menurut data Tatu Vanhanen IPR-nya 
sebesar 10,4\% (Vanhanen, 1997: 88, 146, 253, dan 272).

Pada kondisi pelaksanaan pemilu dan sosialekonomi dan budaya tersebut pengaruhnya terhadap demokrasi dan proses demokrasi di Malaysia secara umum tidak signifikan, kecuali pada tahun 1972 1973. Data empiriknya: (1) periode Pemerintahan Tunku Abdul Rahman menurut data Tatu Vanhanen indeks demokratisasinya sebesar 5,3\%-10,8\% (Vanhanen, 1997: 147 dan 163) dan trend otiritas pemeritahannya menurut Monty G. Marshal and Keith Jaggers menurun dari +10 menjadi +1 (Marshal dan Jaggers, 2006) ${ }^{3}$, (2) periode pemerintahan Tun Abdul Razak-Hussein Onn menurut data Freedom House tingkat kebebasan sebesar 2,5-3,5 (Freedom House, 2006), menurut data Tatu Vanhanen indeks demokratisasi 10,1\%-11,5\% (Vanhanen, 1997: 88, 146, 253 dan 272), dan trend otoritasnya menurut data Monty G. Marshal and Keith Jaggers meningkat dari +1 menjadi +4 (Marshal dan Jaggers, 2006), dan (3) periode Pemerintahan Mahathir Mohamad menurut data Freedom House tingkat kebebasan sebesar 3-5 (Freedom House, 2006), menurut data Tatu Vanhanen indeks demokratisasinya 14,9\% (Vanhanen, 1997: 88, 146, 253 dan 272), dan trend otoritasnya menurut data Monty G. Marshal and Keith Jaggers menurun dari +4 menjadi +3 (Marshal dan Jaggers, 2006).

Berdasarkan bentuk rezim politik dan pemerintahannya menurut data tersebut: (1) periode pemerintahan Tunku Abdul Rahman, akhir Pemerintahan Tun Abdul Razak, Pemerintahan Hussein Onn, dan Mahathir Mohamad bentuk rezim politik dan pemerintahan demokrasi parsial, (2) awal periode pemerintahan Tun Abdul Razak bentuk rezimnya otoriter, dan (3) pertengahan periode pemerintahan Tunku Abdul Razak tahun 1972-1973 bentuk rezimnya demokrasi (Freedom House, 2006; International IDEA, 2008).

Dalam konteks proses demokrasi atau demokratisasi menurut data-data tersebut, periode pemerintahan: (1) Tunku Abdul Rahman menurut perspektif Tatu Vanhanen tidak terjadi demokratisasi di Malaysia dan menurut Monty G. Marshal and Keith Jaggers terjadi arus balik demokratisasi dari rezim demokrasi kepada rezim anokrasi, (2) Tun Abdul Razak-Hussein Onn, tahun 1970-1973 menurut perspektif Freedom House terjadi demokratisasi melalui jalur transformasi dari rezim otoriter kepada rezim demokrasi, menurut Tatu Vanhanen tidak terjadi demokratisasi, dan perspektif Monty G. Marshal tidak terjadi demokratisasi dan hanya meningkatkan otoritas rezim anokrasi, dan (3) Mahathir Mohamad menurut perspektif Freedom House tidak terjadi demokratisasi, menurut Tatu Vanhanen tidak mengalami demokratisasi, dan menurut Monty G. Marshal tidak terjadi demokratisasi dan bahkan mengalami penurunan otoritas rezim anokrasi.

\section{KESIMPULAN}

Berdasarkan data penelitian dapat disimpulkan bahwa pelaksanaan pemilu tidak berpengaruh signifkan atau positif terhadap demokrasi dan proses demokrasi di Malaysia pada periode Pemerintahan Tunku Abdul Rahman hingga Mahthir Mohamad. Sedangkan faktor kondisi sosial-ekonomi dan budaya berpengaruh secara parsial terhadap demokrasi dan proses demokrasi di Malaysia pada periode pertengahan Pemerintahan Tun Abdul Razak tahun 1972-1973. Bentuk rezim politik dan pemerintahan Malaysia, pada periode pemerintahan Tunku Abdul Rahman adalah demokrasi parsial, pemerintahan NOC otoriter, pemerintahan Tun Abdul Razak tahun 1972-1973 berubah menjadi rezim demokrasi liberal, akhir pemerintahan Tunku Abdul Razak hingga Mahathir Mohamad kembali berubah menjadi rezim demokrasi parsial.

Fakta tersebut memperlihatkan bahwa selama periode Pemerintahan Malaysia tahun 1957-2003: (1) pelaksanaan pemilu tidak berpengaruh terhadap demokrasi dan proses demokrasi di Malaysia, (2) praktik pemilu tidak demokratis di Malaysia tidak selalu berada di bawah rezim tidak demokrasi, (3) peningkatan kondisi sosial-ekonomi dan budaya secara umum tidak memberikan pengaruh signifikan 
terhadap demokrasi dan proses demokrasi di Malaysia, kecuali pada Pemerintahan Tun Abdul Razak tahun 1972 dan 1973 yang melahirkan demokrasi liberal, dan (4) rezim politik dan pemerintahan selama periode Pemerintahan Tunku Abdul Rahman hingga Mahathir Mohamad tidak konstan pada setiap periode pemerintahan di Malaysia.

\section{CATATAN AKHIR}

Freedom House mengukur demokrasi liberal/tingkat kebebasan dengan menggunakan skala 1-7. Skor 1-2,5 berarti bebas, skor 2,55,5 berarti setengah bebas, dan skor 5,5-7 berarti tidak bebas.

2 IPR merupakan indeks sosial-ekonomi. Kondisi ekonomi dihitung dari Index of Occupational Diversification (IOD)-Economic Power Resources (DER) dan sosial-budaya dari Index of Knowledge Distribution (IKD). Komponen-komponen variabel IPR meliputi variabel IOD, IKD, dan DER. Variabel IOD sub-variabelnya meliputi Urban Population (UP) dan Non Agricultural Population (NAP), IKD sub-variabelnya meliputi persentase pelajar dan melek huruf, dan DER sub-variabelnya meliputi Agricultural Population (AP), Degree of Decentralization of Non Agricultural Economic Resource (DD), Family Farms (FF), dan Non Agricultural Population (NAP). Perhitungan variabel-variabel tersebut: (1) IPR = IOD $\times$ IKD $\times$ DER/ 10.000, (2) IOD = nilai tengah (mean) penjumlahan antara UP dan NAP, (3) IKD = nilai tengah (mean) penjumlahan pelajar dan melek huruf, (4) DER $=($ FF $\times$ AP) $+(D D \times N A P)$.

3 Monty G. Marshal and Keith Jaggers menggunakan skala dalam mengukur demokrasi. Skalanya kontinum -10 (otoriter) hingga +10 (demokrasi): (1) skala -10 sampai dengan -6 rezim otokrasi, (2) skala -5 sampai dengan +5 rezim anokrasi, (3) skala +6 sampai dengan +10 rezim demokrasi.

\section{BIBLIOGRAFI}

Abas, Mohamed Salleh bin. 1968. Prinsip Pelembagaan dan Pemerentahan di Malaysia. Kuala Lumpur: Dewan Bahasa dan Pustaka Kementrian Pelajaran Malaysia.

Abdullah, Haslinda et al. 2007. "Human Resources Development Strategies: The Malaysian Scenario." Journal of Social Science 3, No. 4: 213-222

Ahmad, Zakaria Haji and Sharifah Munirah Alatas. 1999. "Malaysia: In an Uncertain Mode." James W. Morley (ed.). Driven by Growth: Political Change in the Asia-Pacific Region, pp. 176-196, rev. edn Pasir Panjang, Singapore: Institute of Southeast Asian Studies.

Alvares, Mike et al. 1999. "Data Set 1950-1990." Democracy and Development: Institutions and Material Well-Being in the World, 1950-1990. (Online), (http://www.pantheon.yale.edu 326/ research.html, diakses 10 September 2008).

Bank, World. 2008. 2008 World Development Indicators Online. (Online), (http://go.worldbank.org, diakses 31 Januari 2009).

Bedlington, Stanley S. 1997. "Proses Politik di Malaysia." Colin MacAndrews dan Mohtar Mas'oed (ed.). Perbandingan Sistem Politik, hlm. 233-246, cet. 14. Yogyakarta: Gadjah Mada University Press.
Denzin, Norman K., and Yvonna S. Lincoln. 1994. "Introduction Entering the Field of Qualitative Research." Norman K. Denzin and Yvonna S. Lincoln (eds.), Handbook of Qualitative Research, pp. 117. Thousand Oaks, California: Sage Publications Inc.

Diamond, Larry. 2002. "Elections Without Democracy: Thinking about Hybrid Regimes." Journal of Democracy 13, No. 2 (April): 21-35.

. 2003. Developing Democracy toward Consolidation, Tim IRE (terj.). Yogyakarta: Institute for Research and Empowerment (IRE).

Di Palma, Giuseppe. 1997. Kiat Membangun Demokrasi: Sebuah Esei tentang Transisi Demokrasi, Marianto S., dan Budi Murdono (terj.). Jakarta: Yayasan Sumber Agung.

Esposito, John L. dan John O. Voll. 1999. Demokratisasi di Negaranegara Muslim: Problem dan Prospek. Bandung: Mizan.

Guan, Lee Hock. 2000. "Ethnic Relations in Peninsular Malaysia: The Cultural and Economic Dimensions." Derek da Cunha et al (eds.). Social and Cultural Issues. Institute of Southeast Asian Studies, No. 1 (January): 1-39.

Hai, Lim Hong. 2002. "Electoral Politics in Malaysia: 'Managing' Elections in a Plural Society." Aurel Croissant et al (eds.). Electoral Politics in Southeast and East Asia, pp. 101-148. Singapore: Friedrich Ebert Stiftung.

Held, David. 1996. Models of Democracy. California: Stanford University.

Heufers, Rainer. 2002. "The Politics of Democracy in Malaysia." Asien, 85, S (October, 2002): 39-60.

House, Freedom. 2006. Freedom in World Country Ratings 19722006. (Online), (http://www.freedomhouse.org, diakses 13 Juli 2008).

Huberman, A. Michael and Matthew B. Miles. 1994. "Data Management and Analysis Methods." Norman K. Denzin and Yvonna S. Lincoln (eds.), Handbook of Qualitative Research, pp. 428-444. Thousand Oaks, California: Sage Publications Inc.

Huntington, Samuel P. 1992. "Prospek Demokrasi." Roy C. Macridis dan Bernard E. Brown (penyunting). Perbandingan Politik, hlm. 75-124, A. R. Henry Sitanggang (terj.). Jakarta: Erlangga. . 1995. Gelombang Demokratisasi Ketiga, Asril Marjohan (terj.). Jakarta: Pustaka Utama Grafiti.

IDEA, International. 2008. Malaysia: Electoral System FPTP, Parliamentary Elections. (Online), (http//mww.idea.int.org/esd/glossary/ cfm\#fptp, diakses 3 Agustus 2008).

Johnson, Deborah A., and Anthony Milner. 2005. "Westminster Implanted: The Malaysian Experience." Haig Patapan et al., (eds.), Westminster Legacies: Democracy and Responsible Government in Asia and the Pacific, pp. 81-108. Sidney: UNSW Press.

Koon, Heng Pek. 1996. "Chinese Response to Malay Hegemony in Peninsular Malaysia 1957-1996." Southest Asian Studies 34, No. 3 (December): 32-55.

. 1997. "The New Economic Policy and the Chinese Community in Peninsular Malaysia." The Developing Economies XXXV, No. 3 (September): 262-292.

Malaysia, EPU (Economic Planning Unit). 2001. Keluaran dalam Negeri Kasar dan Pendapatan Negara Kasar pada Harga Semasa. (Online), (http://www.epu.jpm.my/newfolder/ses/pdf, diakses 9 Februari 2009).

Malaysia, Government of. t.th. Constitution of Malaysia. (Online), (http://www.pmr.gov, diakses 9 Maret 2008). 
Marshal, Monty G., and Keith Jaggers. 2006. Polity IV Country Report: Malaysia. (Online), (http://www.cidcm.umd.edu/inscr/polity, diakses 18 September 2008).

Milne, R. S., and Diane K. Mauzy. 1978. Politics and Government in Malaysia. Singapore: Federal Publications.

Mohamad, Mahathir. 1999. Kebangkitan Semula Asia, Mohd Safar Hasim (terj.). Selangor: Pelanduk Publications (M) Sdn Bhd.

Moleong, Lexy J. 2000. Metode Penelitian Kualitatif. Bandung: PT Remaja Rosdakarya.

Neuman, W. Lawrence. 2000. Social Research Methods. Boston: Allyn and Bacon, 2000.

Pennings, Paul et al. 2006. Doing Research in Political Science: An Introduction to Comparative Methods and Statistics. London: Sage Publications Inc.

Potter, David. 1997. "Explaining Democratization." David Potter et al (eds.). Democratization, pp. 1-40. Cambridge and Malden: Polity Press and Open University.

Ragin, Charles C., et al. 1996. "Political Methodology: Qualitative Methods." Robert E. Goodin and Hans-Dieter Klingemen (eds.). A New Handbook of Political Science, pp. 749-768. New York: Oxford University Press.

Rihoux, Benoît. 2008. "Case-Oriented Configurational Research: Qualitative Comparative Analysis (QCA), Fuzzy Sets, and Related Techniques." Janet M. Box-Steffensmeier et al (eds.), The Oxford Handbook of Political Methodology, pp. 722-736. New York: Oxford University Press.

Schumpeter, Joseph A. 1987. Capitalism, Socialism and Democracy. London: Unwin PaperBacks.

Sorensen, Georg. 2003. Demokrasi dan Demokratisasi: Proses dan Prospek dalam Sebuah Dunia yang Sedang Berubah. Yogyakarta: Pustaka Pelajar dan Center for Critical Social Studies.

UNDP (United Nations Development Programme). 1994. Human Development Report 1994. New York: UNDP. 2006. Malaysia International Trade, Growth, Poverty Reduction and Human Development. Kuala Lumpur: UNDP. 2007. Human Development Report 2007-2008. New York: UNDP.

Vanhanen, Tatu. 1997. Prospects of Democracy: A Study of 172 Countries. London and New York: Routledge.

Varshney, Ashutosh. 1998. "India Defies the Odds: Why Democracy Survives." Journal of Democracy 9, No. 3 (July): 36-50.

Verhulst, Jos and Arjen Nijeboer. 2007. Direct Democracy Facts and Arguments about the Introduction of Initiative and Referendum. Brussels: Democracy International.

Wilhelmsen, Lars. 2006. "A Democratic Peace Revisited Measuring Democracy in International." Thesis, Department of Political Science, University of Oslo. 